\title{
Analysis of IMP3 Expression in Prostate Adenocarcinomas
}

\section{Prostat Adenokarsinomlarında IMP-3 Ekspresyonunun Araştırılması}

\author{
Hülya TOSUN YILDIRIM, Nilay ŞEN TÜRK \\ Department of Medical Pathology, Pamukkale University, Faculty of Medicine, DENIZLI, TURKEY
}

\begin{abstract}
Objective: Prostate cancer is the second most common cause of male cancer deaths after lung cancer in developed countries. The prognostic factors currently identified for prostate carcinoma include preoperative serum PSA, TNM staging system, histological grade and surgical margin status and are composed of the clinically most important and useful parameters. However, all the markers studied have not been applied in clinical practice. The oncofetal protein Insulin-Like Growth Factor II has been demonstrated to be associated with aggressive tumor behavior in many organs including urothelial tumors and renal cell carcinoma. Our aim was to investigate the expression status of Insulin-Like Growth Factor II in benign prostate glands, high grade PIN and prostate adenocarcinoma, and to determine the role of Insulin-Like Growth Factor II in pathogenesis of prostate adenocarcinoma.
\end{abstract}

Material and Method: A total of 70 prostate adenocarcinoma cases accompanied by high grade PIN and benign prostate glands were evaluated by immunohistochemistry for the expression of Insulin-Like Growth Factor II.

Results: Insulin-Like Growth Factor II expression was not seen in any of the 70 prostate adenocarcinoma and high grade PIN cases and benign prostate glands.

Conclusion: Although the number of our cases was limited, our results suggested that Insulin-Like Growth Factor II protein expression was not included in the pathogenesis of the prostate adenocarcinomas and Insulin-Like Growth Factor II expression status cannot be used for diagnosis of prostate adenocarcinomas.

Key Words: Prostate, Adenocarcinoma, Insulin-like growth factor II, Pathogenesis
ÖZ

Amaç: Prostat adenokarsinomu, gelişmiş ülkelerde erkeklerde, kansere bağlı ölümler sıralamasında, akciğer kanserinden sonra ikinci sırada yer almaktadır. Günümüzde prostat karsinomlarında tanımlanan prognostik faktörler içinde preoperatif serum prostat spesifik antijen değeri, TNM sistemi esas alınarak evreleme, histopatolojik derece ve cerrahi sınırlar klinik olarak hasta takibinde en önemli ve yararlı parametreleri oluşturmaktadır. Bununla birlikte, prostat adenokarsinomlarıyla ilgili çalışmalarda kullanılan belirteçlerin hiçbirisi, klinik uygulamaya geçirilememiştir. Onkofetal bir protein olan insülin benzeri büyüme faktörü II, mesane ve böbrek tümörlerini içeren birçok organda yapılan çalışmada, agresif gidişli tümörlerle ilişkili bulunmuştur. Çalışmada amacımız, benign prostatik glandlar, yüksek dereceli prostatik intraepitelyal neoplazi ve prostat adenokarsinomlarında insülin benzeri büyüme faktörü II ekspresyon farkını değerlendirerek, prostat adenokarsinomlarının patogenezinde insülin benzeri büyüme faktörü II'nin rolünü aydınlatmaya çalışmaktır.

Gereç ve Yöntem: Çalışmada 70 prostat adenokarsinomu tanılı olgu yer aldı. Her olguda tümör alanı ve buna eşlik eden yüksek dereceli PIN alanları ile benign glandüler yapılar, immünohistokimyasal olarak insülin benzeri büyüme faktörü II ekspresyonu açısından değerlendirildi.

Bulgular: Çalışmada yer alan 70 prostat adenokarsinom olgusunda ve bunlarda tümöre eşlik eden yüksek dereceli PIN alanları ile benign glandüler yapılarda insülin benzeri büyüme faktörü II ekspresyonu saptanmadi.

Sonuç: Olgu sayımız sınırlı olmakla birlikte elde ettiğimiz bulgular, İnsülin benzeri büyüme faktörü II proteinin prostat adenokarsinomlarının patogenezinde yer almadığını ve insülin benzeri büyüme faktörü II ekspresyon durumunun prostat adenokarsinomlarında tanısal amaçlı kullanılamayacağını göstermektedir.

Anahtar Sözcükler: Prostat, Adenokarsinom, İnsülin benzeri büyüme faktörü II, Patogenez

\section{INTRODUCTION}

Prostate adenocarcinoma takes second place following lung cancer as a cause of male cancer-related deaths in developed countries (1). The incidence of prostate cancer increases with age and $75 \%$ of the cases are 65 years of age or older

(Turk Patoloji Derg 2012, 28:128-133)

Received : 19.08.2011 Accepted : 20.12.2011
(2). It is quite rare in children, adolescents and young adults (1).

The etiopathogenesis of prostate cancer is still not clear but hormonal, genetic and environmental factors are thought to play a role in the tumor pathogenesis. Prognostic factors

Correspondence: Hülya TOSUN YILDIRIM

Department of Medical Pathology, Pamukkale University, Faculty of

Medicine, DENIZLİ, TURKEY

E-mail: drhulyatosun@gmail.com Phone: +90 5436856341 
for prostate carcinoma that have currently been defined are preoperative serum prostate-specific antigen (PSA) value, TNM system-based staging, histopathological grade and surgical margins, which constitute the most important and beneficial parameters for patient follow-up while none of the markers used for prostate adenocarcinomas in relevant studies have actually entered clinical practice (2).

The status of insulin-like growth factor-II mRNA binding protein-3 (IMP-3) has been investigated in many solid organ tumors in recent years and is held mainly responsible for cellular proliferation, adhesion and invasion in malignant tumors (3). Although IMP-3 expression has recently been studied in various organs and tissues and especially the urogenital system, kidney and the bladder, there is only one study as far as we know on IMP-3 expression in prostate adenocarcinomas (4-9). Our aim in this study was to try to elucidate the role of IMP-3 in the pathogenesis of prostate adenocarcinomas by checking the IMP-3 expression difference between benign prostate glands, high-grade prostatic intraepithelial neoplasia (PIN) and prostate adenocarcinomas. Finding a significant difference for expression between the groups would indicate that IMP-3 could be an immunohistochemical marker to use in the routine diagnosis of prostate adenocarcinoma.

\section{MATERIAL and METHODS}

We retrospectively evaluated 70 radical prostatectomy material diagnosed as prostate adenocarcinoma between January 2005 and December 2010 in this study. Sections obtained from paraffin-embedded tissue samples fixed in $10 \%$ formaldehyde solution were reevaluated for Gleason score, high-grade PIN, perineural invasion and surgical margins. All cases were also re-evaluated regarding the World Health Organization (WHO) 2004 classification and pathological $\mathrm{T}$ staging was performed (3). The clinical information for the cases including age, gender and preoperative serum PSA values were obtained from pathology reports.

Paraffin blocks that included high-grade PIN, perineural invasion and benign glandular structures together with tumor were chosen for each case. Sections 4-5 micron thick were placed on poly-L-lysine coated slides for IMP-3 immunohistochemical investigation. The sections were kept in a $56-60^{\circ} \mathrm{C}$ autoclave for one night for the first deparaffinization procedure. The immunohistochemical staining of the sections was then performed on fully automatic immunohistochemistry device (VENTANA Bechmark/LT, Ventana Medical Systems, USA). Primary antibody used for the sections was IMP-3 monoclonal antibody (dilution: 1/50, Clone: 69.1, Code: L523S, Dako SA, Glostrup, Denmark). Cytoplasmic staining seen in neuroendocrine lung carcinoma tumor cells was used as the positive control.

The presence of benign glandular structures, high grade PIN and presence of IMP-3 protein expression in tumor tissue were evaluated immunohistochemically. When evaluating the immunohistochemical stains for IMP-3 antibody, the total section was revealed for each case using 10x magnification of the microscope (NIKON Eclipse E200) and the presence or absence of positive staining was evaluated. Positive staining for IMP-3 was accepted in the presence of dark brown cytoplasmic staining in epithelial cells that could be easily seen with low magnification $(\leq 40 \mathrm{x})$. The staining was accepted as negative in case of weak, fine granular background staining in epithelial cells that could not be seen under low magnification $(\leq 40 \mathrm{x})$ or when there was no staining at all.

All analyses were made with the SPSS software (Version 11.0, SPSS Inc., Chicago, IL, USA) and $\chi^{2}$ tests. A p value $<0.05$ was considered significant for the obtained results.

\section{RESULTS}

The age of the cases ranged from 51 to 74 years (mean age $61.94 \pm 5.16)$, and the preoperative serum PSA values were $2.0-46.2 \mathrm{ng} / \mathrm{ml}$ (mean $10.64 \pm 8.03 \mathrm{ng} / \mathrm{ml}$ ).

According to the Gleason scoring system, 20 cases (28.6\%) were Gleason score 6, 44 cases (62.9\%) Gleason score 7,1 case (1.4\%) Gleason score 8 , and 5 cases $(7.1 \%)$ Gleason score 9. The histopathological evaluation of the cases revealed 20 cases $(28.6 \%)$ as grade 2 (moderately differentiated), and 50 cases $(71.4 \%)$ as grade $3-4$ (poorly differentiated). All cases were reevaluated according to the WHO 2004 classification, and 4 cases (5.7\%) were pT2a, 4 cases $(5.7 \%)$ pT2b, 30 cases $(28.6 \%)$ pT 2 c, 20 cases $(28.6 \%)$ pT3a, 10 cases $(14.3 \%)$ pT3b, and 2 cases $(2.9 \%)$ pT3c.

High grade PIN was present in $60(85.7 \%)$ of the 70 cases and absent in 10 (14.3\%). There was perineural invasion in $48(68.6 \%)$ cases and no perineural invasion in 22 (31.4\%). The surgical margins were positive in $12(17.1 \%)$ cases and negative in 58 (82.9\%). Table I summarizes the histopathological features.

Statistical evaluation revealed a statistically significant relationship between histopathological grade and stage $(\mathrm{p}=0.012)$. More advanced $\mathrm{pT}$ stages were found in cases with higher histopathological grade. There was also a statistically significant relationship between the histological grade of the cases and perineural invasion status $(\mathrm{p}=0.034)$. 
Table I: Histopathological findings of the study cases

\begin{tabular}{|c|c|c|}
\hline & Number of patients & Percentage (\%) \\
\hline \multicolumn{3}{|l|}{ Gleason Score } \\
\hline Gleason Score 6 & 20 & 28.6 \\
\hline Gleason Score 7 & 44 & 62.9 \\
\hline Gleason Score 8 & 1 & 1.4 \\
\hline Gleason Score 9 & 5 & 7.1 \\
\hline \multicolumn{3}{|c|}{ Histopathological evaluation } \\
\hline Grade 2 & 20 & 28.6 \\
\hline Grade 3-4 & 50 & 71.4 \\
\hline \multicolumn{3}{|l|}{ pT staging } \\
\hline pT2a & 4 & 5.7 \\
\hline pT2b & 4 & 5.7 \\
\hline pT2c & 30 & 42.9 \\
\hline pT3a & 20 & 28.6 \\
\hline pT3b & 10 & 14.3 \\
\hline pT3c & 2 & 2.9 \\
\hline \multicolumn{3}{|l|}{ High Grade PIN } \\
\hline Yes & 60 & 85.7 \\
\hline No & 10 & 14.3 \\
\hline \multicolumn{3}{|l|}{ Perineural invasion } \\
\hline Yes & 48 & 68.6 \\
\hline No & 22 & 31.4 \\
\hline \multicolumn{3}{|c|}{ Surgical margins positive } \\
\hline Yes & 12 & 17.1 \\
\hline No & 58 & 82.9 \\
\hline
\end{tabular}

We found no statistically significant relationship between histopathological grade of the cases and high-grade PIN, surgical margin positiveness and preoperative serum PSA value ( $\mathrm{p}=0.388 ; \mathrm{p}=0.764 ; \mathrm{p}=0.612$ respectively).

There was no IMP-3 expression in the 70 prostate adenocarcinoma cases and the accompanying high grade PIN areas and benign glandular structures (Figure 1).

\section{DISCUSSION}

Prostate cancer is the most common malignancy in males in developed countries and takes second place after lung cancer among causes of cancer-related mortality. Prostate adenocarcinoma is usually asymptomatic in the early stages since it develops from the peripheral zone and as multifocal small foci. These cases are detected with a suspicious nodule during rectal examination or with an elevated serum PSA level (1). The presence of symptoms usually indicates locally advanced or metastatic disease (2). Early diagnosis is therefore important for effective prostate adenocarcinoma treatment $(4,10)$. Major advances are especially urgently needed for the diagnostic algorithms of

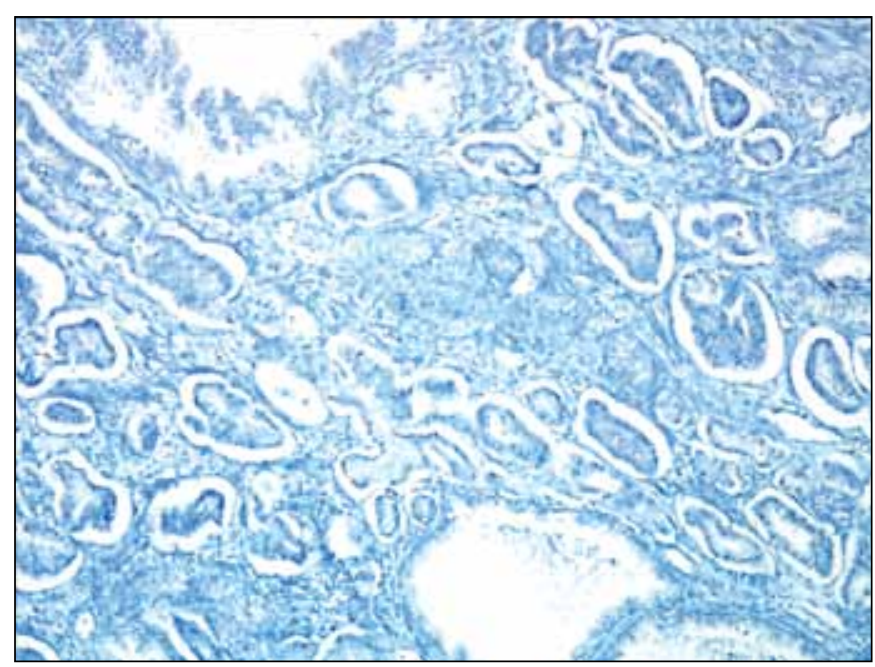

Figure 1: Grade 2 prostate adenocarcinoma with no IMP-3 expression (x200). 
prostate adenocarcinoma regarding the reliable diagnosis of clinically insignificant aggressive prostate adenocarcinomas (4).

High-grade PIN is structurally benign and consists of large ducts and acini lined by atypical cells cytologically. It is frequently seen as multifocal foci in the peripheral zone. High grade PIN is seen in most of the moderately and poorly differentiated prostate adenocarcinomas. Genetic changes similar to prostate adenocarcinoma can also be seen with high-grade PIN. High-grade PIN is therefore assumed to be premalignant and considered a preliminary lesion of prostate adenocarcinoma (1).

Samaratunga et al. defined low risk groups in prostate adenocarcinomas in their study and found that cases with a low Gleason score (histopathological grade) were usually classified in pT1 and pT2a group (11). A study by Andren et al. consisting of 253 prostate adenocarcinoma cases followed up for 20 years found more advanced pT stages in cases with high Gleason scores and reported that the Gleason score was an independent predictive factor for tumor progression (10). Similar to this study, we found advanced pT stages in cases with high histopathological grade.

Lee et al. compared the perineural invasion status and clinicopathological parameters in prostate adenocarcinoma cases of 361 patients and found perineural invasion at a statistically significantly higher rate in cases with high histopathological grades (Gleason score) and reported that the perineural invasion status was significantly related to the tumor's biological aggressive behaviour (12). Similar to this study, we found a higher grade of perineural invasion in cases with higher histopathological grade.

Although the etiopathogenesis of prostate cancer is not clear, it is postulated that hormonal, environmental and genetic factors play a role in the pathogenesis (2). Insulin, one of the hormonal factors, plays a role in cancer etiopathogenesis through cellular proliferation, differentiation and apoptosis. The effects of insulin on prostate cancer development are realized through various mechanisms such as a sympathetic stimulating effect, sex hormone metabolism, the Insulin-like growth factor (IGF) pathway, signal transaction pathway, dyslipidemia and inflammation (13). The IGF family plays a key role in cellular metabolism, differentiation, proliferation, transformation and apoptosis during normal development and malignant growth. The IGF family seems to be necessary for bone metastasis, angiogenesis and androgen-independent progression of prostate cancer (14).
IMP-3 is a member of the IMP family that also contains IMP-1 and 2. The IMP protein family members play a role in RNA interaction and stabilization, cell growth and cell migration of the early stage of embryogenesis (7). The IMP-3 gene is localized in chromosome 7p11.2, and IMP-3, a product of this gene, is a 580 amino acid oncofetal protein. IMP-3 is equivalent to the $\mathrm{K}$ homolog domain containing protein overexpressed in cancer (KOC) protein cloned from pancreatic tumors (15). IMP-3 is expressed in normal epithelium, muscle and placenta during the early stages of human and mouse embryogenesis while it is expressed at very low or undetectable levels in adult tissues (3).

IMP-3 expression status has been investigated in many solid organ tumors in recent years and it is primarily held responsible for cellular proliferation, adhesion and invasion in malignant tumors. IMP-3 regulates the gene expression of IGF-II by binding to the $3 \mathrm{~m}$-RNA region of IGF-II. IGF-II binds to IGF-I and activates IGF-I while stimulating the tyrosine phosphorylation of this receptor. The tyrosine phosphorylated IGF-I receptor sends mitogenic signals to the cell. This is followed by cell cycle regulation loss and apoptotic cycle disturbance and resulting uncontrolled cell proliferation, i.e. carcinogenesis (16).

Overexpression of IMP-3 has been found in many malignant tumors including hepatocellular carcinoma, extrahepatic biliary system, melanocytic lesions, and exocrine pancreas, esophagus and gastric cancers but expression has not been found in adjacent benign tissues (17-22).

Lu et al. have compared IMP-3 expression in invasive esophageal adenocarcinoma, metastatic esophageal adenocarcinoma and high-grade dysplasia with the expression in benign glandular structures, low grade dysplasia and Barett esophagus in their 2009 study and found significantly higher rates in the first group. They stated that IMP-3 possibly plays an important role in the malignant transformation of esophageal adenocarcinoma with these findings (21). Similarly, Riener et al. found significantly higher degrees of strong positive IMP-3 expression in the extrahepatic biliary system in high degree dysplasia than in normal, inflamed and low-grade dysplasia cases. They also found IMP-3 expression to be significantly associated with decreased survival in carcinoma cases (18). So, the oncofetal protein IMP-3 seems to play a critical role in arranging cellular proliferation, tumor invasion and aggressive behaviour (6).

IMP-3 expression has been extensively studied in kidney and bladder tumors in the urogenital system (5-8). Jiang et al. studied 501 localized primary and metastatic renal cellular carcinoma (RCC) cases and found IMP-3 
expression to be significantly higher in the metastatic RCC group than the localized primary RCC group. They also found the metastasis-independent 5 year survival rate to be significantly lower in IMP-3 positive localized primary RCC cases than IMP-3 negative localized primary RCC cases (7). Jiang et al. studied 334 primary papillary and chromophobe RCC cases and found IMP-3 expression to be significantly increased in the metastasis developing groups for both RCC subtypes (8). Hoffman et al. have studied IMP-3 expression in 716 clear cell RCC cases and reported similar to Jiang et al. that IMP-3 expression was an independent predictive factor for aggressive behaviour $(7,8,23)$.

Sitnikova et al. studied IMP-3 expression in a total of 242 primary superficial bladder urothelial carcinoma and metastatic urothelial carcinoma cases and found IMP3 expression to be positive in $20 \%$ of primary superficial bladder urothelial carcinoma cases and $93 \%$ of metastatic urothelial carcinoma cases. They also found IMP-3 positive urothelial carcinoma cases to have lower progressionindependent and disease-independent survival rates (6). Li et al. investigated IMP-3 expression in benign urothelium and urothelial tumors and did not find IMP-3 expression in low grade urothelial tumors including benign urothelium and urothelial dysplasia, papillary urothelial neoplasms with low malignant potential and low grade papillary urothelial carcinomas. However, they found significantly higher IMP3 expression in high grade urothelial tumors including high grade papillary urothelial carcinoma, urothelial carcinoma in situ and invasive urothelial carcinoma (5). A study by Özdemir et al. on benign urothelium, non-invasive and invasive urothelial carcinomas found low IMP-3 expression in benign urothelium and low and high grade non-invasive urothelial carcinomas while there was a statistically significantly higher IMP-3 expression in low and high grade invasive urothelial carcinoma cases. These finding and the other studies indicate that IMP-3 expression can be related to aggressive tumor behaviour in urothelial carcinomas (9).

The cases in our study were classified according to the WHO 2004 classification. Benign prostate tissue and highgrade PIN were also included in the study. Metastatic prostate adenocarcinomas were not included in our study. All cases were analysed for IMP-3 expression. Although we found IMP-3 expression in positive controls and internal controls, we did not find IMP-3 expression in the 70 prostate adenocarcinoma cases and the accompanying high-grade PIN areas and benign glandular structures in our study. Ikenberg et al. have investigated IMP-3 expression with the tissue microarray method in total of 505 cases consisting of 31 normal prostate tissues, 425 primary prostate adenocarcinomas and 51 metastatic or castration resistant prostate adenocarcinomas. The single study investigating IMP-3 expression in prostate adenocarcinoma has found no IMP-3 expression in $16.7 \%$ of normal prostate tissue and primary prostate adenocarcinomas (71 cases) while weak expression was found in $69.2 \%$ (294 cases), moderate expression in $13.4 \%$ (57 cases) and strong expression in $0.7 \%$ (3 cases) of the primary prostate adenocarcinomas. IMP-3 expression was not observed in $25.5 \%$ of the metastatic or castration-resistant prostate adenocarcinoma cases (13 cases) while there was weak expression in $58.8 \%$ (30 cases) moderate expression in 5.9\% (3 cases) and strong expression in $9.8 \%$ ( 5 cases). When compared to normal prostate tissue, they found IMP-3 expression to be significantly higher in prostate cancer. However, this expression was not found to be associated with the pT stage, Ki-67 proliferation index, preoperative serum PSA value and surgical boundaries. They have only stated that IMP-3 expression may be weakly or mildly significantly associated with the Gleason score but this had little value regarding the prognostic significance in the clinical and pathologic correlation analysis of prostate adenocarcinomas (4). When we compare the Ikenberg et al. study on IMP-3 expression in prostate adenocarcinomas and our study, we were unable to show staining in any of our cases although we used the antibody from the same clone as theirs and in a more concentrated manner. Our number of cases was quite limited compared to the Ikenberg et al. study and did not include any metastatic cases. Despite our limited number of cases, our findings indicate that the IMP-3 protein does not play a role in prostate adenocarcinoma pathogenesis and IMP-3 expression status cannot be used for diagnostic purposes in prostate adenocarcinomas.

In conclusion, IMP-3 oncofetal protein has been shown to play a role in malignant transformation in many malignant tumors including the hepatobiliary system, esophagus, gastric, pancreas, and urothelial tumors, and melanocytic lesions. It has also been said to possibly be a sensitive and specific marker for the diagnosis of the invasive tumor and high-grade dysplasia in these tumors. However, our findings show that IMP-3 plays no role in the malignant transformation of prostate adenocarcinomas in contrast to tumors in many other systems. It therefore does not seem possible to use it in diagnostic algorithms for the reliable diagnosis of clinical insignificant aggressive prostate cancers. 


\section{REFERENCES}

1. Bostwick DG, Meiers I: Neoplasms of the Prostate. In Bostwick DG, Cheng L. (Eds): Urologic Surgical Pathology. 2nd ed., Missouri, Mosby-Elsevier, 2008, 444-578

2. Eble JN, Sauter G, Epstein JI, Sesterhenn IA: World Health Organization classification of tumours. Pathology and genetics of tumours of the urinary system and male genital organs. Lyon, IARC Pres, 2004, 160-215

3. Mueller-Pillasch F, Pohl B, Wilda M, Lacher U, Beil M, Wallrapp C, Hameister H, Knöchel W, Adler G, Gress TM: Expression of the highly conserved RNA binding protein KOC in embryogenesis. Mech Dev 1999, 88:95-99

4. Ikenberg K, Fritzsche FR, Zuerrer-Haerdi U, Hofmann I, Hermanns T, Seifert H, Müntener M, Provenzano M, Sulser T, Behnke S, Gerhardt J, Mortezavi A, Wild P, Hofstädter F, Burger M, Moch H, Kristiansen G: Insulin-like growth factor II mRNA binding protein 3 (IMP3) is overexpressed in prostate cancer and correlates with higher Gleason scores. BMC Cancer 2010, 10:341

5. Li L, Xu H, Spaulding BO, Cheng L, Simon R, Yao JL, di Sant'Agnese PA, Bourne PA, Huang J: Expression of RNAbinding protein IMP3 (KOC) in benign urothelium and urothelial tumors. Human Pathol 2008, 39:1205-1211

6. Sitnikova L, Mendese G, Liu Q, Woda BA, Lu D, Dresser K, Mohanty S, Rock KL, Jiang Z: IMP3 predicts aggressive superficial urothelial carcinoma of the bladder. Clin Cancer Res 2008, 14:1701-1706

7. Jiang Z, Chu PG, Woda BA, Rock KL, Liu Q, Hsieh CC, Li C, Chen W, Duan HO, McDougal S, Wu CL: Analysis of RNAbinding protein IMP3 to predict metastasis and prognosis of renal-cell carcinoma: a retrospective study. Lancet Oncol 2006, 7:556-564

8. Jiang Z, Lohse CM, Chu PG, Wu CL, Woda BA, Rock KL, Kwon ED: Oncofetal Protein IMP3: A novel molecular marker that predicts metastasis of papillary and chromophobe renal cell carcinomas. American Cancer Society 2008, 112: 2676-2682

9. Özdemir NO, Türk NŞ, Düzcan E: IMP-3 expression in urothelial carcinomas of the urinary bladder. Türk Patoloji Dergisi 2011, 27:31-37

10. Andren O, Fall K, Franzen L, Andersson SO, Johansson JE, Rubin MA: How well does the Gleason score predict prostate cancer death? A 20-year followup of a population based cohort in Sweden. J Urol 2006, 175:1337-1340

11. Samaratunga H, Epstein JI: What is the molecular pathology of low-risk prostate cancer? World J Ural 2008, 26:431-436
12. Lee JT, Lee S, Yun CJ, Jeon BJ, Kim JM, Ha HK, Lee W, Chung MK: Prediction of perineural invasion and its prognostic value in patients with prostate cancer. Korean J Urol 2010, 51:745-751

13. Nandeesha $\boldsymbol{H}$ : Insulin: a novel agent in the pathogenesis of prostate cancer. Int Urol Nephrol 2009, 41:267-272

14. Gennigens C, Menetrier-Caux C, Droz JP: Insulin-Like Growth Factor (IGF) family and prostate cancer. Crit Rev Oncol Hematol 2006, 58:124-145

15. Monk D, Bentley L, Beechey C, Hitchins M, Peters J, Preece MA, Stanier P, Moore GE: Characterisation of the growth regulating gene IMP3, a candidate for Silver-Russel syndrome. J Med Genet 2002, 39:575-581

16. Liao B, Hu Y, Herrick DJ, Brewer G: The RNA-binding protein IMP-3 is a translational activator of insulin-like growth factor II leader-3 mRNA during proliferation of human K562 leukemia cells. J Biol Chem 2005, 280:18517-18524

17. Jeng YM, Chang CC, Hu FC, Chou HY, Kao HL, Wang TH, Hsu HC: RNA-binding protein insulin-like growth factor II mRNA-binding protein 3 expression promotes tumor invasion and predicts early recurrence and poor prognosis in hepatocellular carcinoma. Hepatology 2008, 48:1118-1127

18. Riener MO, Fritzsche FR, Clavien PA, Pestalozzi BC, ProbstHensch N, Jochum W, Kristiansen G: IMP3 expression in lesions of the biliary tract: a marker for high-grade dysplasia and an independent prognostic factor in bile duct carcinomas Hum Pathol 2009, 40:1377-1383

19. Yu L, Xu H, Wasco MJ, Bourne PA, Ma L: IMP-3 expression in melanocytic lesions. J Cutan Pathol 2010, 37:316-322

20. Yantiss RK, Woda BA, Fanger GR, Kalos M, Whalen GF, Tada H, Andersen DK, Rock KL, Dresser K: KOC (K homology domain containing protein overexpressed in cancer): a novel molecular marker that distinguishes between benign and malignant lesions of the pancreas. Am J Surg Pathol 2005, 29:188-195

21. Lu D, Vohra P, Chu PG, Woda B, Rock K, Jiang Z: An oncofetal protein IMP3: a new molecular marker for the detection of esophageal adenocarcinoma and high-grade dysplasia Am J Surg Pathol 2009, 33:521-525

22. Jeng YM, Wang TH, Lu SH, Yuan RH, Hsu HC: Prognostic significance of insulin-like growth factor II mRNA-binding protein 3 expression in gastric adenocarcinomas. Br J Surg 2009, 96:66-73

23. Hoffmann NE, Sheinin Y, Lohse CM, Parker AS, Leibovich BC, Jiang Z, Kwon ED: External validation of IMP3 expression as an independent prognostic marker for metastatic progression and death for patients with clear cell renal cell carcinoma. Cancer 2008, 112:1471-1479 